\title{
RELATIONSHIP BETWEEN SPECIES RICHNESS OF EXCAVATOR BIRDS AND CAVITY-ADOPTERS IN SEVEN TROPICAL FORESTS IN COSTA RICA
}

\author{
LUIS SANDOVAL ${ }^{1,2}$ AND GILBERT BARRANTES ${ }^{1}$
}

\begin{abstract}
The abundance of wood cavities is thought to be a limiting factor for bird species that depend on these cavities for nesting. Thus, it is expected that number of cavity adopters correlates with number of cavity excavators across communities. We used available published data to compare composition and richness of cavity adopters and cavity excavators across seven forest localities in Costa Rica. Species richness and composition of cavity excavator and cavity adopter bird assemblages varied among the seven forests. Species composition of excavators and adopters was more similar between nearby localities and between localities with similar forest types. Richness of wood-cavity adopters (using mostly cavities created by excavators) tended to increase with richness of excavators. The lack of association between cavity adopters and cavity excavators in some localities may be compensated by high abundance of a few species of excavators. The abundance of adopters and their dependence on forested habitats and on cavities excavated by woodpeckers varied largely across localities. Received 6 November 2007. Accepted 4 May 2008.
\end{abstract}

Bird nests vary greatly in shape and construction (Baicich and Harrison 1997, Collias 1997, Sheldon and Winkler 1999), including cavity nests (Skutch 1976; Eberhard 1998, 2002). Among cavity nesters, some bird species nest in clay or sand cavities (e.g., beeeaters, motmots, jacamars, kingfishers) (Skutch 1976), other species nest in cavities excavated in termitaria or wasp nests (e.g., trogons, parrots) (Juniper and Parr 1998, Johnsgard 2000, Brightsmith 2004), and another group nests in natural cavities or cavities constructed by other birds in branches or dead trunks of broken, or fungi-infested trees (e.g., woodpeckers, ducks, swallows, owls) (Rendell and Robertson 1989, Belthoff and Ritchison 1990, Conner et al. 2001).

Birds nesting in tree cavities are generally classified into three groups: cavity excavators (excavators), wood-cavity adopters or secondary cavity nesters (adopters), and weak cavity excavators (for our purpose we include these birds in the previous category) (Schepps et al. 1999, Aitken et al. 2002, Eberhard 2002). Excavators construct their own nests, investing a large amount of time and energy in their construction (Conner et al. 1976, Martin 1993). Adopters nest in natural cavities (cavities not constructed by other birds), or in abandoned

\footnotetext{
${ }^{1}$ Escuela de Biología, Universidad de Costa Rica, San Pedro de Montes de Oca, Costa Rica.

${ }^{2}$ Corresponding author; e-mail: biosandoval@ hotmail.com
}

cavities excavated by other birds, or usurp occupied cavity nests (Wesolowski 2000, Aitken et al. 2002). The population size of both groups may be limited by the presence of appropriate sites for nesting (Rudolph and Conner 1991, Schepps et al. 1999). Excavators are limited by the suitability of appropriate substrates to construct their cavities, whereas cavity adopters are likely affected by the abundance of suitable nesting cavities.

There is considerable variation among wood-cavity adopters in selection of nest cavities and, consequently, considerable variation in dependence on cavities excavated by excavators (Aitken et al. 2002). In Costa Rica, tityras and pygmy-owls use mostly pre-dug holes, mainly by woodpeckers (Skutch 1946, Marin and Schmitt 1991; pers. obs.). The majority of wood-cavity adopters, such as flycatchers (Young and Zook 1999), parrots (Lanning 1991, Juniper and Parr 1998), swallows (Rendell and Robertson 1989), falcons (Mader 1979), and macaws (Vaughan et al. 2003), use natural and/or pre-dug cavities for nesting. The dependence of adopters on cavities dug by excavators has been better studied in North American and European forests (Petit et al. 1985, Aitken et al. 2002, Giese and Cuthbert 2003). Little is known about selection and dependence of adopters on cavities dug by excavators in the Neotropics.

Standing dead trees in tropical forests suitable for cavity construction are likely more limited than in temperate forests (Gibbs et al. 
TABLE 1. Climatic variables and elevation for selected forest localities in Costa Rica.

\begin{tabular}{lcccc}
\hline \multicolumn{1}{c}{ Locality } & \multicolumn{1}{c}{ Coordinates } & $\begin{array}{c}\text { Mean annual } \\
\text { temperature }\left({ }^{\circ} \mathrm{C}\right)\end{array}$ & $\begin{array}{c}\text { Mean annual } \\
\text { rainfall }(\mathrm{mm})\end{array}$ & Elevation $(\mathrm{m})$ \\
\hline Palo Verde & $10^{\circ} 21^{\prime} \mathrm{N}, 85^{\circ} 21^{\prime} \mathrm{W}$ & 24.0 & 1,500 & $5-100$ \\
Santa Rosa & $10^{\circ} 18^{\prime} \mathrm{N}, 84^{\circ} 48^{\prime} \mathrm{W}$ & 25.7 & 1,750 & $0-317$ \\
Las Cruces & $08^{\circ} 47^{\prime} \mathrm{N}, 82^{\circ} 57^{\prime} \mathrm{W}$ & 20.1 & 3,937 & 1,100 \\
La Selva & $10^{\circ} 26^{\prime} \mathrm{N}, 83^{\circ} 59^{\prime} \mathrm{W}$ & 25.8 & 3,962 & $35-150$ \\
Villa Mills & $09^{\circ} 33^{\prime} \mathrm{N}, 83^{\circ} 42^{\prime} \mathrm{W}$ & 10.9 & 2,679 & 3,000 \\
Osa & $08^{\circ} 33^{\prime} \mathrm{N}, 83^{\circ} 30^{\prime} \mathrm{W}$ & 27.4 & 6,241 & $0-745$ \\
Monteverde & $10^{\circ} 15^{\prime} \mathrm{N}, 84^{\circ} 46^{\prime} \mathrm{W}$ & 18.8 & 2,519 & $1,200-1,800$ \\
Central Valley & $09^{\circ} 56^{\prime} \mathrm{N}, 84^{\circ} 02^{\prime} \mathrm{W}$ & 20.0 & 1,902 & 1,200 \\
\hline
\end{tabular}

1993) because dead trees decompose faster in tropical environments. Conversely, this faster decomposing rate may create more available substrates to excavate cavities. As with temperate species (e.g., Picoides borealis, Rudolph and Conner 1991; Melanerpes erythrocephalus, Conner and Adkisson 1977), a few tropical woodpeckers apparently have selectivity for dead substrates for excavating their cavities (Sandoval and Barrantes 2006). Selection of dead trees and alternative substrates (e.g., termite nests) in which to construct their cavities is poorly known for most tropical species.

Our objectives were to: (1) describe the species composition of the wood-cavity excavator and wood-cavity adopter avifaunas in seven forest localities in Costa Rica, and (2) examine the relationship between species richness of wood cavity excavators and cavity adopters in each forest locality. We additionally examined the relationship between these two groups and the total avifauna in each community. Many adopter species nest primarily in wood cavities excavated by excavator species; consequently, a high correlation was expected between these two groups of species across communities.

\section{METHODS}

We gathered information on species composition and abundance, and cavity nesting behavior (cavity-excavators or cavity-adopters) for all birds nesting in wood cavities in seven forest localities in Costa Rica from Stiles (1983), Stiles and Skutch (1989), and complemented this information with our own data. Birds excavating in other types of substrates (e.g., motmots, kingfishers) were excluded since few other species adopt their cav- ities. The seven localities include different forest types: dry forest (Palo Verde and Santa Rosa National parks), montane forest (Monteverde), rain forest (La Selva Biological Station and Península de Osa), premontane forests (Las Cruces Biological Station and Central Valley), and high montane forest (Villa Mills). Palo Verde and Santa Rosa were combined as Guanacaste because of their proximity and similarity in forest characteristics. Forest vegetation of these localities was described by Hartshorn (1983) and Haber (1999). Climatic features of these seven forests varied (Table 1).

We classified each adopter into three cavity nesting categories: $0=$ only nest in natural cavities, 1 = nest either in natural or woodpecker-excavated cavities, and $2=$ nest primarily in cavities excavated by woodpeckers (Appendix). We also classified species by forest dependence following Stiles (1985) where 1 corresponds to species that inhabit mature forests, $2=$ species that live in habitats with $50 \%$ or less forest cover, and $3=$ species that inhabit open areas. Species that Stiles (1985) scored as 1-2 and 2-3 were re-classified as 1.5 and 2.5, respectively. Bird species were also classified as abundant, common, uncommon, or rare following Stiles (1983) (abundance data are lacking for most Costa Rican species).

Only breeding species at each locality with scores for cavity nesting category of 1 or 2 were included in our statistical analyses. We conducted a cluster analysis (nearest neighbor) based on Sørensen's Similarity Index (Magurran 1988) to examine similarities in species composition of cavity nesters (excavators and adopters combined) among localities. Pearson correlations were used to analyze 
TABLE 2. Correlation between bird abundance (A), nesting behavior (NB), and forest dependence (FD) with the three first vectors of the bi-plot analysis in seven forest localities in Costa Rica.

\begin{tabular}{lllr}
\hline & \multicolumn{3}{c}{ Vector } \\
\cline { 2 - 4 } \multicolumn{1}{c}{ Locality } & \multicolumn{1}{c}{1} & \multicolumn{1}{c}{2} & \multicolumn{1}{c}{3} \\
\hline Guanacaste & $\mathrm{A}=0.84$ & $\mathrm{NB}=0.67 \mathrm{FD}=-0.71$ & $\mathrm{~A}=-0.54$ \\
La Selva & $\mathrm{A}=0.69 \mathrm{FD}=0.70$ & $\mathrm{NB}=-0.82$ & $\mathrm{~A}=0.63 \mathrm{FD}=-0.65$ \\
Osa & $\mathrm{A}=-0.70 \mathrm{FD}=0.73$ & $\mathrm{NB}=0.84$ & $\mathrm{FD}=0.65$ \\
Las Cruces & $\mathrm{A}=0.79 \mathrm{FD}=0.81$ & $\mathrm{NB}=-0.95$ & $\mathrm{~A}=0.55 \mathrm{FD}=-0.57$ \\
Villa Mills & $\mathrm{NB}=-0.94$ & $\mathrm{FD}=-0.89$ & $\mathrm{NB}=0.33$ \\
Monteverde & $\mathrm{NB}=0.82$ & $\mathrm{FD}=0.86$ & $\mathrm{~A}=-0.51 \mathrm{NB}=0.55$ \\
Central Valley & $\mathrm{A}=0.86 \mathrm{FD}=0.80$ & $\mathrm{NB}=0.76$ & $\mathrm{~A}=0.49 \mathrm{FD}=-0.41$ \\
\hline
\end{tabular}

whether the total number of excavators was correlated with total number of adopters. This analysis was also used to examine the relationship between numbers of excavators with number of adopters with a score of 1 , and with number of adopters with a score of 2 . We also correlated the total number of species for each locality that do not use cavities for nesting using excavators and adopters with score 1, and adopters with score 2 .

We first conducted a bi-plot analysis including the abundance category, forest dependence, and cavity nesting behavior for each species to evaluate differences in these variables between both adopter groups (those with score 1 or score 2 ) at each locality. This analysis is appropriate when categorical variables are used to classify species, and the scores from this analysis are continuous variables that can be used to test further hypotheses (Gotelli and Ellison 2004). The bi-plot analysis groups species in a multidimensional space defined by $n$-vectors that result from combination of the original variables. We selected the first three vectors that explained $>90 \%$ of the total variance and obtained three scores for each species, one from each vector. The first vector was associated primarily with bird abundance in five localities, forest dependence in four, and nesting behavior in two localities (Table 2). The second vector was associated with cavity nesting behavior in five localities, and forest dependence in three (Table 2). The third vector was associated with the three variables but to a lesser extent than the previous two vectors (Table 2). We conducted a MANOVA with these scores, using the nesting category (score 1 and score 2) as a grouping variable. The nesting categories indicate the extent of dependence of adopters for cavities constructed by excavators. Woodpeckers were included in this analysis in the score 2 category because they use exclusively cavities they construct for nesting. Use of MANOVA allowed us to test whether birds that we classified as nesting in natural and/or woodpecker-excavated cavities differed from those species that nest primarily in cavities excavated by woodpeckers, based on scores (from bi-plot analysis) that combine forest dependence, abundance, and cavity nesting behavior (excavator or adopter) of each species. Number of excavators and adopters for each abundance category were compared in each locality using a Chi-square homogeneity test.

\section{RESULTS}

We found 94 wood-cavity nesting species, representing $11 \%$ of the Costa Rican avifauna, in the seven localities (Appendix). The number of species that nested in cavities ranged from eight to 55 across localities. The total number of adopters and excavators was high in La Selva, Península de Osa, and Las Cruces (Table 3). Similarity of cavity nesting avifaunas was $79.4 \%$ between Las Cruces and Península de Osa (Fig. 1), both in the southern Pacific of Costa Rica, and $65 \%$ between Península de Osa and La Selva, the two rainforest avifaunas. The similarity of the avifauna of the high-montane forest in Villa Mills was lowest when compared with any other locality (Fig. 1).

The total number of adopters and adopters with score 1 (species that nest either in natural or woodpecker excavated cavities) did not correlate with total number of excavators $(r=$ $0.62, P=0.14 ; r=0.51, P=0.25$, respectively). However, number of adopters with score 2 (species that nest primarily in cavities 
TABLE 3. Number of cavity-nesting birds per category of abundance and dependence on use of cavities excavated by woodpeckers in seven Costa Rica localities. Parentheses $=$ number of primary cavity excavators. * indicates significant differences $(P<0.05)$ between excavators and adopters within each category of abundance, using a Chi-square homogeneity test.

\begin{tabular}{|c|c|c|c|c|c|c|c|}
\hline \multirow[b]{2}{*}{ Locality } & \multicolumn{4}{|c|}{ Abundance $^{\mathrm{a}}$} & \multicolumn{3}{|c|}{ Dependence $^{\mathrm{b}}$} \\
\hline & Abundant & Common & Uncommon & Rare & Some & High & $n^{\mathrm{c}}$ \\
\hline Guanacaste & $8(1)^{*}$ & $7 *$ & $8(3)$ & $9(1)$ & 16 & 9 & 36 \\
\hline Las Cruces & $3(1)$ & $16(7)$ & $10(6)$ & $5(1)$ & 13 & 21 & 43 \\
\hline La Selva & $10(2)$ & $11(4)$ & $13(4)$ & $9(3)$ & 22 & 21 & 55 \\
\hline Villa Mills & & $2(2)$ & $2(1)$ & $4(1)$ & 1 & 7 & 8 \\
\hline Osa & $4(1)$ & $18(9)$ & $11(3)$ & 1 & 19 & 15 & 47 \\
\hline Monteverde & $2(1)$ & $12(4)$ & $5(3)$ & $4(2)$ & 8 & 15 & 34 \\
\hline Central Valley & $2(1)$ & $5(1)$ & 1 & $3(1)$ & 5 & 6 & 14 \\
\hline
\end{tabular}

a Abundance categories follow Stiles (1983).

${ }^{\mathrm{b}}$ Cavity dependence is based on Stiles and Skutch (1989).

${ }^{\mathrm{c}} n=$ number of species nesting in natural cavities.

excavated by woodpeckers), tended to increase with number of excavators $(r=0.72$, $P=0.07)$. The richness of adopters with score 1 and excavators was not correlated with number of species that do not use cavities for nesting present at each locality $(r=0.68, P=$ $0.36 ; r=0.68, P=0.36$, respectively). However, adopters with score 2 were positively correlated with the total number of species that do not use cavities for nesting at each locality ( $r=0.94, P=0.006)$.

The group for two of the seven localities constituted by adopters with score 2 (high dependence on cavities excavated by woodpeck-

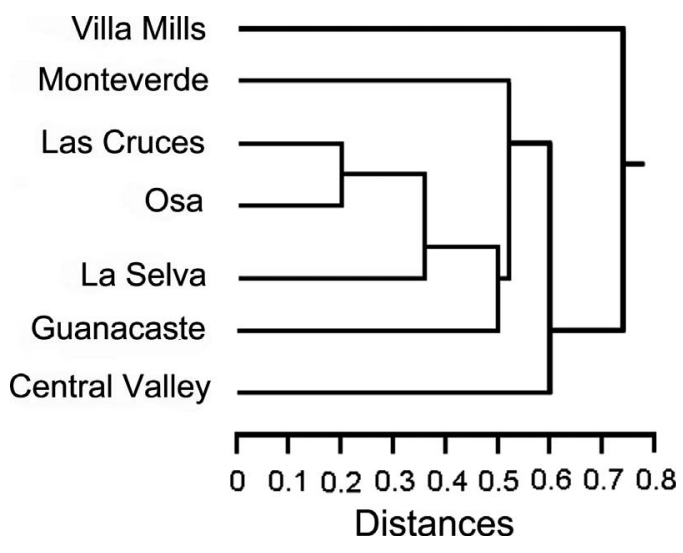

FIG. 1. Similarities among species composition of cavity nesting birds from seven forests in Costa Rica, based on the Sørensen Similarity Index. Composition of cavity nesting birds of Villa Mills differs most in relation to the other localities, whereas Las Cruces and Osa have the most similar composition of cavity nesting birds. ers for nesting) and woodpeckers differed from adopters with score 1 (based on MANOVA analyses): Guanacaste $\left(F_{3,21}=6.33, P\right.$ $=0.003)$ and Península de Osa $\left(F_{3,29}=3.54\right.$, $P=0.027)$. The difference between groups (score 1 vs. score 2 species) was nearly significant at Las Cruces $\left(F_{3,26}=2.48, P=0.08\right)$, but no significant differences were detected between both groups at La Selva $\left(F_{3,35}=1.86\right.$, $P=0.15)$, Villa Mills $\left(F_{3,4}=0.42, P=0.75\right)$, Monteverde $\left(F_{3,16}=2.60, P=0.89\right)$, and Central Valley $\left(F_{3,4}=0.74, P=0.58\right)$. The number of species (excavators vs. adopters) per abundance category did not vary across localities, except in Guanacaste where the number of cavity excavators was much lower than expected in two abundance categories: abundant and common (Table 3).

\section{DISCUSSION}

The number of adopters and excavators at each locality reflects, at least partially, the overall richness and composition of the avifauna of each locality. For example, La Selva and Península de Osa with the richest avifaunas in Costa Rica (Stiles 1983), also had the highest number of adopters and excavators, whereas the low number of species in both groups present at Villa Mills, reflected its poor avifauna diversity.

Similarities in avifaunal composition are affected by similarity of habitat and distance between localities (Stiles 1983). Villa Mills shared more species with Monteverde and, to a lesser extent with the Central Valley, the other highland localities. The largest similar- 
ity of cavity-nesting species was between the closest localities (Península de Osa and Las Cruces). The second most similar pair of localities, Península de Osa and La Selva, was likely the result of similarities in vegetation (rainforest) that covers both regions (Hartshorn 1983).

Our results showed a lack of correlation between total number of excavators and the total number of adopters. The absence of correlation likely resulted from some (or many) adopters using primarily natural cavities rather than cavities constructed by woodpeckers. Termite and wasp nests are common in some forests (Santa Rosa and Palo Verde) (Lubin 1983), and these structures are frequently used by parakeets (e.g., Aratinga canicularis and Brotogeris jugularis) and trogons (e.g., Trogon melanocephalus) to construct their cavities. Natural cavities, such as those produced by decomposition in broken branches, are also frequently used by many adopters. The use of the abundant natural cavities in some localities may relax the dependence of some adopters on cavities excavated by woodpeckers.

Number of adopters that use primarily cavities excavated by woodpeckers tended to increase with number of excavators, and significantly increased with total number of species that do not use cavities for nesting in each locality. This indicates that number of adopters in a given locality relies, at least in part, on number and possibly on abundance of excavators to access appropriate cavities for nesting. Furthermore, in five localities forest dependence, abundance, and nesting behavior (represented by the bi-plot scores) did not differ between species with different dependence on cavities excavated by wood excavators (species with cavity dependence with score 1 or 2).

The reduced number of cavity excavator species in some forest localities may be compensated by high abundance of a few excavator species. Adopters in the dry forest (Guanacaste) depend on only two excavator species, Hoffmann's Woodpecker (Melanerpes hoffmannii) and the uncommon Lineated Woodpecker (Dryocopus lineatus). Hoffmann's Woodpecker is abundant and constructs many cavities during each breeding season (pers. obs.). Most adopters (e.g., Tityra semifasciata, Aratinga canicularis, Brotogeris jugularis, Myiarchus tyrannulus) in the dry forest are similar in size to Hoffmann's Woodpecker, and these species can use this woodpecker's cavities for nesting without having to modify them. Other species (e.g., Amazona albifrons) can modify woodpecker cavities for nesting. More detailed studies are needed to establish a cause-effect relationship between richness and abundance of excavators and adopters.

Climatic conditions, including rainfall, wind, and storms may affect abundance and longevity of cavities made by cavity excavators. For example, high precipitation and wind storms likely make cavities more ephemeral in tropical forests, where trees and branches fall more frequently than in temperate forests (Gibbs et al. 1993, Denslow and Hartshorn 1994). These conditions may also affect the association between adopters and excavators in tropical forests, contrary to temperate forests where adopters and excavators frequently have a strong association (Martin and Eadie 1999). However, little is known about the effect of climatic conditions on the abundance of nesting cavities in tropical forests.

The number (and percent) of cavity nesting species varies among neotropical forests (Monterrubio-Rico and Escalante-Pliego 2006, Cornelius et al. 2008). Despite this variation, it is clear that birds nesting in wood cavities constitute an important component of the neotropical avifauna (Gibbs et al. 1993). However, cavity-nesting birds have received little attention, particularly from a conservation view. The destruction of enormous forested areas in the Neotropics (Skole and Tucker 1993, Lobo et al. 2007) largely threaten wood-cavity nesting birds. This group of birds is particularly susceptible to forest destruction as construction and use of their nesting cavities depend directly on the presence of trees. Even alternative forestry practices, such as extraction of standing dead trees, will increase the risk of extinction of local populations of wood-cavity nesting birds (Newton 1994).

\section{ACKNOWLEDGMENTS}

We thank Cintia Cornelius, Kristina Cockle, J. W. Wiley, C. E. Braun, and an anonymous reviewer for valuable comments that largely improved the early draft of the manuscript. 


\section{LITERATURE CITED}

AitKen, K., K. Wiebe, And K. Martin. 2002. Nest-site reuse patterns for a cavity-nesting bird community in interior British Columbia. Auk 119:391-402.

BAICICH, P. AND C. HARRISON. 1997. Nests, eggs and nestlings of North American birds. Princeton University Press, Princeton, New Jersey, USA.

Belthoff, J. AND G. Ritchison. 1990. Nest-site selection by Eastern Screech-owls in central Kentucky. Condor 92:982-990.

BRIGHTSMITH, D. 2004. Nest sites of termitarium nesting birds in SE Peru. Ornitología Neotropical 15: 319-330.

Collias, N. 1997. On the origin and evolution of nest building by passerine birds. Condor 99:253-270.

Conner, R. N. And C. S. Adkisson. 1977. Principal component analysis of woodpecker nesting habitat. Wilson Bulletin 89:122-129.

Conner, R. N., O. K. Miller JR., AND C. S. AdKISSON. 1976. Woodpecker dependence on trees infected by fungal heart rot. Wilson Bulletin 88:575-581.

Conner, R. N., C. E. Shackelford, D. SAenz, and R. R. SchAEFER. 2001. Interactions between nesting Pileated Woodpeckers and Wood Ducks. Wilson Bulletin 113:250-253.

Cornelius, C., K. Cockle, N. Politi, I. Berkunsky, L. Sandoval, V. Ojeda, L. Rivera, M. Hunter JR., AND K. MARTIN. 2008. Cavity nesting birds in neotropical forests: cavities as a potentially limiting resource. Ornitología Neotropical 19:253268.

Denslow, J. S. And G. S. Hartshorn. 1994. Tree-fall gap environments and forest dynamic processes. Pages 120-127 in La Selva. Ecology and natural history of a neotropical rain forest (L. A. McDade, K. S. Bawa, H. A. Hespenheide, and G. S. Hartshorn, Editors). University of Chicago Press, Chicago, Illinois, USA.

EBERHARD, J. 1998. Evolution of nest-building behavior in Agapornis parrots. Auk 115:455-464.

EBERHARD, J. 2002. Cavity adoption and evolution of coloniality in cavity-nesting birds. Condor 104: 240-247.

Gibis, J., M. Hunter JR., And S. Melvin. 1993. Snag availability and communities of cavity nesting birds in tropical versus temperate forest. Biotropica 25:236-241.

Giese, C. L. A. And F. J. Cuthbert. 2003. Influence of surrounding vegetation on woodpecker nest tree selection in oak forests of the Upper Midwest, USA. Forest Ecology and Management 179:523534.

Gotelli, N. J. And A. M. Ellison. 2004. A primer of ecological statistics. Sinauer Associates Publisher, Sunderland, Massachusetts, USA.

HABER, W. 1999. Plants and vegetation. Pages 39-70 in Monteverde, ecology and conservation of a tropical cloud forest (N. Nadkarni and N. Wheelwright, Editors). Oxford University Press, New York, USA.
HARTShORN, G. 1983. Plants: introduction. Pages 118158 in Costa Rican natural history (D. H. Janzen, Editor). Chicago University Press, Chicago, Illinois, USA.

JohnsGard, P. 2000. Trogons and quetzals of the world. Smithsonian Institution Press, Washington, D.C., USA.

Juniper, T. AND M. PARr. 1998. Parrots, a guide to parrots of the world. Yale University Press, New Haven, Connecticut, USA.

LANNING, D. 1991. Distribution and breeding biology of the Red-fronted Macaw. Wilson Bulletin 103: 351-365.

Lobo, J., G. Barrantes, M. Castillo, R. Quesada, T. Maldonado, E. J. Fuchs, S. Solís, And M. QueSADA. 2007. Effects of selective logging on the abundance, regeneration and short-term survival of Caryocar costaricense (Caryocaceae) and Peltogyne purpurea (Caesalpinaceae), two endemic timber species of southern Central America. Forest Ecology and Management 245:88-95.

LubIN, Y. 1983. Nasutitermes (Comejen, Hormiga Blanca, Nasute Termite, Arboreal Termite). Pages 749-751 in Costa Rican natural history (D. H. Janzen, Editor). Chicago University Press, Chicago, Illinois, USA.

MADER, W. 1979. First nest description for the genus Micrastur (Forest Falcons). Condor 81:320.

Magurran, A. E. 1988. Ecological diversity and its measurement. Princeton University Press, Princeton, New Jersey, USA.

Marin, M. AND J. SchmitT. 1991. Nests and eggs of some Costa Rican birds. Wilson Bulletin 103: 506-509.

Martin, K. And J. M. EAdie. 1999. Nest webs: a community-wide approach to the management and conservation of cavity-nesting forest birds. Forest Ecology and Management 115:243-257.

MARTin, T. 1993. Evolutionary determinants of clutch size in cavity-nesting birds: nest predation or limited breeding opportunities? American Naturalist 142:937-946.

Monterrubio-Rico, T. C. and P. Escalante-Pliego. 2006. Richness, distribution and conservation status of cavity nesting birds in Mexico. Biological Conservation 128:67-78.

Newton, I. 1994. The role of nest sites in limiting the numbers of hole-nesting birds: a review. Biological Conservation 70:265-276.

Petit, D. R., K. E. Petit, T. C. Grubb, and L. J. ReichHARDT. 1985. Habitat and snag selection by woodpeckers in a clear-cut: an analysis using artificial snags. Wilson Bulletin 97:525-533.

Rendell, W. B. AND R. J. Robertson. 1989. Nest-site characteristics, reproductive success and cavity availability for Tree Swallows breeding in natural cavities. Condor 91:875-885.

Rudolph, D. C. AND R. N. Conner. 1991. Cavity tree selection by Red-cockaded Woodpeckers in relation to tree age. Wilson Bulletin 103:458-467.

SANDOval, L. AND G. BarRantes. 2006. Selección de 
árboles muertos por el Carpintero de Hoffmann (Melanerpes hoffmannii) para la construcción de nidos. Ornitología Neotropical 17:295-300.

Schepps, J., S. Lohr, AND T. MARTin. 1999. Does tree hardness influence nest-site selection by primary cavity nesters? Auk 116:658-665.

SHeldon, F. AND D. WinKLeR. 1999. Nest architecture and avian systematics. Auk 116:875-877.

SKole, D. AND C. TuCKer. 1993. Tropical deforestation and habitat fragmentation in the Amazon: satellite data from 1978 to 1988. Science 260:1905-1910.

Skutch, A. 1946. Life history of the Costa Rican Tityra. Auk 63:327-362.

SkUTCH, A. 1976. Parent birds and their young. University of Texas Press, Austin, USA.

Stiles, F. G. 1983. Checklist of birds. Pages 530-544 in Costa Rican natural history (D. H. Janzen, Editor). Chicago University Press, Chicago, Illinois, USA.

STILES, F. G. 1985. Conservation of forest birds of Costa Rica: problems and perspectives. Pages 121138 in Conservation of tropical forest birds, (A. W. Diamond, and T. S. Lovejoy, Editors). Technical Publication Number 4, International Council for Bird Preservation, Cambridge, United Kingdom.

Stiles, F. G. And A. F. Skutch. 1989. Guide to the birds of Costa Rica. Cornell University Press, Ithaca, New York, USA.

Vaughan, C., N. Nemeth, and L. Marineros. 2003. Ecology and management of natural and artificial Scarlet Macaw (Ara macao) nest cavities in Costa Rica. Ornitología Neotropical 14:1-16.

Wesolowski, T. 2000. What happens to old nests in natural cavities? Auk 117:498-500.

YounG, B. AND J. ZooK. 1999. Nesting of four poorly known bird species on the Caribbean slope of Costa Rica. Wilson Bulletin 111:124-128.

\section{APPENDIX}

We classified 94 species of birds that nest in wood cavities in seven Costa Rican forest localities into four groups: natural cavity nesters, low dependence wood-cavity adopters, primary wood-cavity adopters, and excavators. Natural cavity nesters may use wood nesting cavities, but these cavities are not suitable to be used by adopters.

Natural cavity nesters-Cathartidae: $\mathrm{Ca}$ thartes aura, C. burrovianus, Sarcoramphus papa; Falconidae: Herpetotheres cachinnans, Micrastur semitorquatus; Psittacidae: Ara ambiguus, A. macao; Tytonidae: Tyto alba; Strigidae: Pulsatrix perspicillata; Dendrocolaptidae: Deconychura longicauda, Dendrocincla homochroa, Dendrocolaptes sanctithomae, Glyphorhynchus spirurus, Sittasomus griseicapillus, Xiphorhynchus lachrymosus, X. Susurrans; and Formicariidae: Formicarius analis, $F$. nigricapillus.

Low dependence wood-cavity adopters (species with score 1, some species occasionally build cavities*)_Anatidae: Dendrocygna autumnalis, Cairina moschata; Falconidae: Micrastur ruficollis; Psittacidae: Aratinga canicularis, A. finschi*, Brotogeris jugularis, Amazona albifrons, A. auropalliata, A. autumnalis, A. farinosa; Strigidae: Megascops choliba, M. cooperi, M. guatemalae; Trogonidae: Trogon clathratus, T. massena*, T. rufus*, T. violaceus; Ramphastidae: Ramphastos sulfuratus, R. swainsonii; Dendrocolaptidae: Dendrocincla anabatina, D. fuliginosa, Lepidocolaptes affinis, L. souleyetii, Xiphorhynchus erythropygius; Furnariidae: Philydor rufum; Tyrannidae: Conopias albovittatus, Myiarchus nuttingi, M. panamensis, M. tyrannulus, Myiodynastes luteiventris, M. maculates; and Hirundinidae: Progne chalybea, Notiochelidon cyanoleuca, Tachycineta albilinea.

Primary wood-cavity adopters (species with score 2) and cavity excavators (species that excavate their own wood cavities*)_ Psittacidae: Pyrrhura hoffmanni*, Pionopsitta haematotis*, Pionus senilis; Strigidae: Strix virgata, Glaucidium brasilianum, G. costaricanum, G. griseiceps; Trogonidae: Pharomachrus mocinno*, Trogon collaris, T. bairdii*, T. elegans; Ramphastidae: Aulacorhynchus prasinus, Eubucco bourcierii*, Pteroglossus frantzii, P. torquatus, Selenidera spectabilis, Semnornis frantzii*; Picidae: Picumnus olivaceus*, Melanerpes formicivorus*, $M$. chrysauchen $^{*}$, M. pucherani*, M. rubricapillus*, M. hoffmannii*, Sphyrapicus varius*, Picoides villosus*, Veniliornis fumigatus $*$, V. kirkii*, Piculus simplex*, P. rubiginosus *, Celeus loricatus *, C. castaneus*, Dryocopus lineatus*, Campephilus guatemalensis*; Dendrocolaptidae: Dendrocolaptes picumus*, Xiphocolaptes promeropirhynchus ; Furnariidae: Pseudocolaptes lawrencii, Xenops minutus $^{*}, X$. rutilans; Tyrannidae: Colonia colonus; and Cotingidae: Tityra semifasciata, $T$. inquisitor. 